\title{
Online Exercise Program for Elderly During Coronavirus (Covid-19) Pandemic
}

DOI: $10.26466 /$ opus.934919

\author{
*

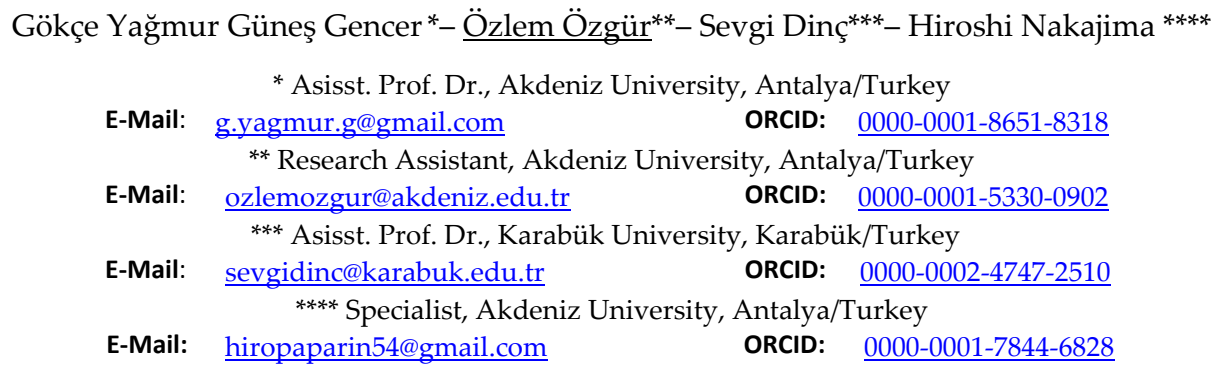

\begin{abstract}
It was conducted to determine the benefits of exercise for the elderly who were restricted from curfew due to the coronavirus (Covid-19) epidemic and the technological competence of older individuals in accessing exercise. This study was conducted with the students in 60+ Tazelenme University, between March and May 2020. The sample of the study is 80 people. The elderly participated in the online exercise for eight weeks, during the three months when there was a curfew for the elderly. The Information Form, which was prepared by the researchers by reviewing the literature, was used to collect the data, evaluating the benefits of online exercise and the ability of the elderly to access online exercise. The data were collected online via "Google Forms". 66.0\% of the individuals participating in the present study were between the ages of 60-69. It has been observed that the online exercise study affects the physical and psychological health of the participants. 96.7\% of the seniors believed that online exercise during the quarantine improved their health. $95.6 \%$ of the elderly noted that exercise improves the quality of life, and 98,9\% reported that it helps daily life activities. Also, $94.6 \%$ of the participants think that they have sufficient technological equipment. Although the elderly experienced some difficulties following the during exercises online, the majority were able to follow and apply the program. It is observed that the online exercise program has a positive effect on the physical and mental well-being of the elderly. The necessity of online exercise programs that can help elderly people stay active is noteworthy during the pandemic.
\end{abstract}

Keywords: Online Exercise, Elderly, Covid-19, Quarantine, Tele-Health. 


\section{Koronavirüs (COVID-19) Salgını Sırasında Yaşlılar İçin Çevrimiçi Egzersiz Programı}

\section{Öz}

Bu çalışma, Koronavirüs (Covid-19) nedeniyle sokă̆a çıkmaları kısıtlanan yaşlılar için çevrimiçi egzersizin faydaların ve yaşlı bireylerin çevrimiçi egzersize erişimdeki teknolojik yeterliliğini belirlemek amacıyla yapıldı. Çalı̧̧ma, 60+ Tazelenme Üniversitesi öğrencileri ile Mart-Mayıs 2020 tarihleri arasında gerçekleştirildi. Araştırmanın örneklemi 80 kişidir. Yaşlı bireyler kendileri için sokă̆a çıkma yasağının olduğu sekiz haftalı süre boyunca çevrimiçi egzersizlere katıldı. Araştırmacılar tarafından literatür taranarak hazırlanan Bilgi Formu, verilerin toplanması, çevrimiçi egzersizin faydalarının ve yaşlların çevrimiç̧i egzersize erişim becerilerinin değerlendirilmesinde kullanıldı. Veriler "Google Formlar" aracılı̆̆ıyla çevrimiçi olarak toplandı. Bu çalışmaya katılan bireylerin\% 66,0' sı 60-69 yaşları arasındadır. Çevrimiçi egzersiz çalışmasının katılımcıların fiziksel ve psikolojik sağlı̆̆ını etkilediği görülmüş̧ür. Yaşlıları \% 96,7' si, karantina sırasında çevrimiçi egzersizin să̆llklarını iyileştirdiğine inanıyordu. Yaşlıların \%95,6 'sı egzersizin yaşam kalitesini artırdı̆̆ını, \%98,9'u ise günlük yaşam aktivitelerine yardımcı olduğunu belirtti. Ayrıca katılımcıların \%94,6'sı yeterli teknolojik donanıma sahip olduklarını düşünmektedir. Yaşlılar çevrimiçi egzersizler sırasında bazı zorluklar yaşasa da, çoğunluk programı takip edip uygulayabildi. Çevrimiçi egzersiz programının yaşlıların fiziksel ve ruhsal iyilik hali üzerinde olumlu bir etkisi olduğu görülmektedir. Salgın sırasında yaşlıların aktif kalmasına yardımcı olabilecek çevrimiçi egzersiz programlarının gerekliliği dikkate değerdir.

Anahtar Kelimeler: Çevrimiçi Egzersiz, Yaşlı, Covid-19, Karantina, Tele-Sağlık. 


\section{Introduction}

The World Health Organization (WHO) announced on January 30, 2020, that the Coronavirus disease (Covid-19) pandemic had become a global health problem in the world. WHO warned people to stay at home during the ongoing Covid-19 pandemic to reduce exposure and infection rates. Taking precautions for infection control is imperative due to the rapid spread of Covid-19. Staying home is one of the most critical measures that can limit the widespread of the coronavirus (Chen et al., 2020). Staying in quarantine at home to control the Covid-19 disease, preventing the virus from being transmitted from person to person, may cause a decline in physical activity. Staying at home for a long time can increase the passive behaviors, such as watching television, playing computer games, and using mobile devices. The decrease in the level of physical activity has a negative effect on the health status of people (Owen et al., 2010). Thus, it is necessary to continue physical activity at home to remain healthy during the quarantine period. A home exercise program with simple, safe, and easy exercises, including stretching, strengthening, and balance (Chen et al., 2020) was suggested to be suitable for increasing and maintaining the level of physical activity (Halabchi, Ahmadinejad and Selk-Ghaffari, 2020).

A certain level of physical activity and exercise is required to ensure active aging in the quarantine period. It is known that the physical activity of the older adults positively affects the prevention of sarcopenia, falling risk, frailty, and cognitive impairment (Cadore, Asteasu and Izquierdo, 2019). Studies have revealed that physical activity and exercises directly affect mental and physical health in combating chronic diseases ( Liu et al., 2019, Anderson and Durstine, 2019) and increase the quality of life (Buffart et al., 2017, Sagar et al., 2015). Therefore, exercise remains vital during quarantine to ensure that seniors maintain an active lifestyle and their general health at home (Jiménez-Pavón, Carbonell-Baeza and Lavie, 2020). During the quarantine days, the importance of exercise in the protection of the physical and mental health of the elderly has increased more. In this period we spend a long time at home, online exercise for the elderly has created an alternative in protecting health. The present study aimed 
to determine the benefit of online exercise on older adults during the quarantine period and the technological competence of older people accessing online exercise.

\section{Method}

The sample population of this prospective study was quarantined adults over 55 years of age who were students of $60+$ Tazelenme University. The $60+$ Tazelenme University is a novel implementation of University of the Third Age (U3A) in Turkey (11). The study sample consists of 100 people who participated in online exercises for eight weeks between March 2020 and May 2020 during the pandemic period. Of these, statistically, at a 95\% confidence interval, the inclusion of 80 participants' data in the study could be considered sufficient (Yazıcıoğlu and Erdoğan, 2007), while 91 participants' data were included in our study. 9 people were not included in the study because they did not fill out the questionnaire. This study was approved by the Institutional Ethics Review Board (ID number 30-491).

Recent studies have shown that basic exercise program components in older adults require stretching, strengthening, balance, and resistance exercises (Sherrington et al, 2008). In our study, the online exercise program included: (a) static stretching (stretching the upper extremities, lower extremities, and both sides of the body), (b) muscle strengthening (extension, stretching, abduction of the shoulders), and hips, elbows, wrists, knees, ankle lengthening and stretching, and (c) balance (heel and toe lifting) and cool-down (deep breathing) exercises were performed. The necessary resistance for muscle strengthening exercises was provided with body weight. Participants aged 55 and over participated in the online exercise for 45 minutes, three days a week for eight weeks. The exercises started with 8-10 repetitions and increased to 15-20 repetitions in the following period.

The Information Form (Appendix.1) generated by the researchers in line with the relevant literature review was used in collecting the data. A combination of open and closed-ended questions were included to evaluate the socio-demographic characteristics of the participants as well as the benefits of online exercise and the competence of older individuals in accessing online exercise. For closed questions answers used the format of a 
typical five-level Likert item: Strongly agree, Agree, Neither agree nor disagree, Disagree, Strongly disagree.

The data were collected online via "Google Forms". All participants ticked the box that they agreed to participate in the study before answering the questions online. The forms were delivered to older people via the WhatsApp program, which is used by many elderly people today.

Quantitative data were evaluated using descriptive statistics (number and percentage) in SPSS 23.0 software. The Cronbach-Alpha method was used to determine the internal consistency of the form. It was reported that the alpha value of 0.80 and above indicates high consistency (Uzunsakal and Yildiz, 2018)

\section{Results}

Considering the age distribution of the individuals participating in this study, $66.0 \%$ of them are between the ages of $60-69$. The majority of the participants were women $(84.6 \%)$, married $(63.7 \%)$, and undergraduate $(35.2 \%)$ individuals. $63.7 \%$ of the older individuals stated that their income is equivalent to their expenses. Hypertension diagnosis (15.4\%) takes the first place among those with chronic diseases. The demographic characteristics of the participants are shown in Table 1.

Table 1. The demographic characteristics of the participants

\begin{tabular}{llll}
\hline Age & & $\mathbf{N}$ & $\mathbf{\%}$ \\
& $55-59$ & 24 & 26,4 \\
& $60-64$ & 24 & 26,4 \\
& $65-69$ & 36 & 39,6 \\
Gender & $70-74$ & 7 & 7,7 \\
& Total & 91 & 100,0 \\
Marital Status & Female & 77 & 84,6 \\
& Male & 14 & 15,4 \\
& Total & 91 & 100,0 \\
& Married & 58 & 63,7 \\
Educational Status & Single & 33 & 36,3 \\
& Total & 91 & 100,0 \\
& Primary school & 5 & 5,5 \\
& High school & 25 & 27,5 \\
& Collage & 25 & 27,5 \\
& Graduate & 32 & 35,2 \\
& Postgraduate & 4 & 4,4 \\
& Total & 91 & 100,0 \\
& Hypertension & 14 & 15,4
\end{tabular}




\begin{tabular}{llll} 
Chronic Diseases & Diabetes & 5 & 5,5 \\
& Cardiovascular Diseases & 7 & 7,7 \\
Cancer & 8 & 8,8 \\
Thyroid Disease & 4 & 4,4 \\
Others & 23 & 25,3 \\
No Disease & 30 & 33,0 \\
Total & 91 & 100,0 \\
\hline
\end{tabular}

Others: migraine, kidney disease, osteoarthritis, osteoporosis

\section{Investigation of internal consistency}

The Cronbach-Alpha method was used to determine the internal consistency of the data form. The Cronbach-alpha value of all 23 items of the form was determined to be 0.878 that indicates high reliability .

$96.7 \%$ of the elderly believed that online exercise in quarantine improves their health. In evaluating the elderly people's thoughts about the effect of exercise on their physical health, $93.4 \%$ of the elderly reported that exercise helps reduce their pain, $97.8 \%$ of them found that exercise prevents the decrease in physical movement ability. Furthermore, 97.8\% of the elderly stated that it protects muscle strength, $97,8 \%$ of them stated that it is suitable for bone and joint health. $89.0 \%$ of the elderly believed that exercise helps keep their weight under control, $89.0 \%$ of them reported that it protects from other diseases (Table 2).

Table 2. The effect of online exercise on physical health

\begin{tabular}{|c|c|c|c|c|c|c|}
\hline & \multirow[t]{2}{*}{ Items } & \multirow{2}{*}{$\begin{array}{l}\begin{array}{l}\text { Strongly } \\
\text { agree }\end{array} \\
\text { n (\%) }\end{array}$} & \multirow{2}{*}{$\begin{array}{l}\text { Agree } \\
\text { n (\%) }\end{array}$} & \multicolumn{2}{|c|}{$\begin{array}{l}\text { Neither agree } \\
\text { nor disagree }\end{array}$} & \multirow{2}{*}{$\begin{array}{l}\begin{array}{l}\text { Strongly disa- } \\
\text { gree }\end{array} \\
\mathbf{n}(\%) \\
\end{array}$} \\
\hline & & & & n (\%) & n (\%) & \\
\hline \multirow{7}{*}{$\begin{array}{l}\text { The effect of } \\
\text { online exercise } \\
\text { on physical } \\
\text { health }\end{array}$} & $\begin{array}{l}\text { I think exercise during quarantine } \\
\text { improves my health. }\end{array}$ & $67(73,6)$ & $21(23,1)$ & $2(2,2)$ & $1(1,1)$ & $0(0)$ \\
\hline & $\begin{array}{l}\text { I think exercise during quarantine } \\
\text { helps me lessen my pain. }\end{array}$ & $56(61,5)$ & $29(31,9)$ & $3(3,3)$ & $2(2,2)$ & $1(1,1)$ \\
\hline & $\begin{array}{l}\text { I think exercise during quarantine } \\
\text { prevents the deterioration of my } \\
\text { physical mobility. }\end{array}$ & $66(72,5)$ & $23(25,3)$ & $2(2,2)$ & $0(0)$ & $0(0)$ \\
\hline & $\begin{array}{l}\text { I think exercise during quarantine } \\
\text { prevents my muscle strength from } \\
\text { decreasing. }\end{array}$ & $61(67,0)$ & $28(30,8)$ & $2(2,2)$ & $0(0)$ & $0(0)$ \\
\hline & $\begin{array}{l}\text { I think exercise during quarantine } \\
\text { is good for my bone and joint } \\
\text { health. }\end{array}$ & $63(69,2)$ & $26(28,6)$ & $1(1,1)$ & $1(1,1)$ & $0(0)$ \\
\hline & $\begin{array}{l}\text { I think exercise during quarantine } \\
\text { helped me keep my weight stable. }\end{array}$ & $53(58,2)$ & $28(30,8)$ & $4(4,4)$ & $6(6,6)$ & $0(0)$ \\
\hline & $\begin{array}{l}\text { I think exercise during quarantine } \\
\text { protects me from other diseases. }\end{array}$ & $41(45,0)$ & $40(44,0)$ & $5(5,5)$ & $5(5,5)$ & $0(0)$ \\
\hline
\end{tabular}


In evaluating the elderly's thoughts about the effect of exercise on their psychological health, $93.4 \%$ of them stated that it is suitable for fatigue, $89.1 \%$ of the elderly found that exercise positively affects the quality of sleep, $92.4 \%$ of them believed that exercise makes them feel good. Moreover, $98.9 \%$ of the elderly remain active with exercise, $95.6 \%$ of them are thinking that the exercise makes them optimistic. $95.6 \%$ of the elderly noted that exercise improves the quality of life, and $98.9 \%$ reported that it helps daily life activities (Table 3).

Table 3. The effect of online exercise on psychological health

\begin{tabular}{|c|c|c|c|c|c|c|}
\hline & Items & $\begin{array}{l}\text { Strongly } \\
\text { agree }\end{array}$ & Agree & $\begin{array}{l}\text { Neither } \\
\text { agree nor } \\
\text { disagree }\end{array}$ & Disagree & $\begin{array}{l}\text { Strongly } \\
\text { disagree }\end{array}$ \\
\hline & & n (\%) & n (\%) & $\mathrm{n}(\%)$ & n (\%) & n (\%) \\
\hline \multirow{7}{*}{$\begin{array}{l}\text { The effect of } \\
\text { online exercise on } \\
\text { psychological } \\
\text { health }\end{array}$} & $\begin{array}{l}\text { I think exercise during quar- } \\
\text { antine reduced my fatigue. }\end{array}$ & $48(52,7)$ & $37(40,7)$ & $3(3,3)$ & $1(1,1)$ & $2(2,2)$ \\
\hline & $\begin{array}{l}\text { I think that exercise during } \\
\text { quarantine has a positive ef- } \\
\text { fect on my sleep quality. }\end{array}$ & $38(41,8)$ & $43(47,3)$ & $10(11,0)$ & $0(0)$ & $0(0)$ \\
\hline & $\begin{array}{l}\text { I think that exercise during } \\
\text { quarantine makes me feel } \\
\text { good. }\end{array}$ & $42(46,2)$ & $42(46,2)$ & $7(7,7)$ & $0(0)$ & $0(0)$ \\
\hline & $\begin{array}{l}\text { I think that exercise during } \\
\text { quarantine helps me stay ac- } \\
\text { tive. }\end{array}$ & $59(64,8)$ & $31(34,1)$ & $1(1,1)$ & $0(0)$ & $0(0)$ \\
\hline & $\begin{array}{l}\text { I think exercise during quar- } \\
\text { antine helps me to be opti- } \\
\text { mistic. }\end{array}$ & $48(52,7)$ & $39(42,9)$ & $3(3,3)$ & $1(1,1)$ & $0(0)$ \\
\hline & $\begin{array}{l}\text { I think exercise during quar- } \\
\text { antine improves my quality } \\
\text { of life. }\end{array}$ & $48(52,7)$ & $39(42,9)$ & $4(4,4)$ & $0(0)$ & $0(0)$ \\
\hline & \multicolumn{2}{|c|}{$\begin{array}{l}\text { I think exercise during quaran- } 48(52,7) \\
\text { tine helps me in daily living ac- } \\
\text { tivities. }\end{array}$} & $42(46,2)$ & $1(1,1)$ & $0(0)$ & $0(0)$ \\
\hline
\end{tabular}

Considering the difficulties experienced by the elderly in following online exercises, $74.8 \%$ of the elderly reported that they have difficulty in performing the movements since they are alone. Furthermore, $66.0 \%$ of the elderly have a visual impairment, $68.2 \%$ reported that hearing problems prevent them from exercise, and $95.7 \%$ of them stated that they have difficulty understanding movements. Due to fatigue, $58.3 \%$ of the elderly; due to pain, $73.7 \%$ stated that they have difficulty exercising (Table 4 ). 
Table 4. The obstacles to participation in an online exercise

\begin{tabular}{|c|c|c|c|c|c|c|}
\hline & Items & $\begin{array}{l}\text { Strongly } \\
\text { agree }\end{array}$ & Agree & $\begin{array}{l}\text { Neither } \\
\text { agree nor } \\
\text { disagree }\end{array}$ & Disagree & $\begin{array}{l}\text { Strongly } \\
\text { disagree }\end{array}$ \\
\hline & & n (\%) & n (\%) & n (\%) & n (\%) & n (\%) \\
\hline \multirow{6}{*}{$\begin{array}{l}\text { The obstacles to } \\
\text { participation in } \\
\text { an online exer- } \\
\text { cise }\end{array}$} & $\begin{array}{l}\text { Since I am alone while exercis- } \\
\text { ing online during quarantine, I } \\
\text { have difficulty performing } \\
\text { movements. }\end{array}$ & $35(38,5)$ & $33(36,3)$ & $13(14,3)$ & $6(6,6)$ & $4(4,4)$ \\
\hline & $\begin{array}{l}\text { I think that vision problem is } \\
\text { an obstacle in using online ex- } \\
\text { ercise during quarantine. }\end{array}$ & $31(34,1)$ & $29(31,9)$ & $17(18,7)$ & $11(12,1)$ & $3(3,3)$ \\
\hline & $\begin{array}{l}\text { I think hearing problem is an } \\
\text { obstacle to using online exer- } \\
\text { cise during quarantine. }\end{array}$ & $30(33,0)$ & $32(35,2)$ & $10(11,0)$ & $14(15,4)$ & $5(5,5)$ \\
\hline & $\begin{array}{l}\text { I think I have difficulty under- } \\
\text { standing movements while ex- } \\
\text { ercising online during quaran- } \\
\text { tine. }\end{array}$ & $42(46,2)$ & $45(49,5)$ & $2(2,2)$ & $1(1,1)$ & $1(1,1)$ \\
\hline & \multicolumn{2}{|c|}{$\begin{array}{l}\text { I think I have difficulty exercis- } 21(23,1) \\
\text { ing during quarantine due to } \\
\text { fatigue. }\end{array}$} & $32(35,2)$ & $7(7,7)$ & $25(27,5)$ & $6(6,6)$ \\
\hline & \multicolumn{2}{|c|}{$\begin{array}{l}\text { I think I have difficulty exercis- } 34(37,4) \\
\text { ing during quarantine because } \\
\text { of pain. }\end{array}$} & $33(36,3)$ & $8(8,8)$ & $11(12,1)$ & $5(5,5)$ \\
\hline
\end{tabular}

Considering the benefits of online exercise for the elderly; $88.1 \%$ of the elderly stated that they felt less lonely by participating in online exercises during the quarantine. $93.5 \%$ of the participants stated that they realized that they could exercise at home without going outside by participating in online exercises during the quarantine. Also, $94.6 \%$ of the participants think that they have sufficient technological equipment (Table 5).

Table 5. The benefits of online exercise

\begin{tabular}{|c|c|c|c|c|c|}
\hline & \multirow[t]{2}{*}{ Items } & \multirow{2}{*}{$\begin{array}{l}\text { Agree } \\
\mathbf{n}(\%) \\
\end{array}$} & \multicolumn{2}{|c|}{$\begin{array}{l}\text { Neither agreeDisagree } \\
\text { nor disagree }\end{array}$} & \multirow{2}{*}{$\begin{array}{l}\text { Strongly } \\
\text { disagree } \\
\text { n (\%) }\end{array}$} \\
\hline & & & n (\%) & n (\%) & \\
\hline & $\begin{array}{l}\text { I think I feel less lonely by partici-37(40,7) } \\
\text { pating in online exercises during } \\
\text { the quarantine. }\end{array}$ & $34(37,4)$ & $14(15,4)$ & $5(5,5)$ & $1(1,1)$ \\
\hline \multirow[t]{2}{*}{$\begin{array}{l}\text { The benefit } \\
\text { exercise }\end{array}$} & $\begin{array}{l}\text { I realized that by participating in } 43(47,3) \\
\text { online exercises during quaran- } \\
\text { tine, I could exercise at home with- } \\
\text { out going outside. }\end{array}$ & $42(46,2)$ & $2(2,2)$ & $3(3,3)$ & $1(1,1)$ \\
\hline & $\begin{array}{l}\text { I think I have enough technological } 43(47,3) \\
\text { tools to take advantage of online } \\
\text { exercise during the quarantine. }\end{array}$ & $43(47,3)$ & $5(5,5)$ & $0(0)$ & $0(0)$ \\
\hline
\end{tabular}


According to the elderly's open-ended questions, one of the most important benefits of exercise is that it prevents them from being inactive and makes them more active. It was stated by the majority of the elderly that exercise is beneficial in reducing muscle and joint pain by enabling the muscles to work. It was emphasized by the elderly that exercise is also effective on psychological well-being. It was observed that exercise had a positive effect on the psychological health of elderly people in terms of being emotionally cheerful, relaxing, doing something useful for oneself, feeling peaceful and happy, relaxing the mind, thinking positively, and feeling well.

Although some of the elderly people stated reasons that prevent them from participating in exercise such as forgetting the starting time of the exercise, caring for their mothers, home and gardening, getting bored with repetitive activities, participating in other online activities, and experiencing some technical difficulties, it was observed that most of them had no problem in participating and following the exercises. Although there are elderly people who believed that continuing with online exercise programs may be beneficial after the quarantine, some of them stated that it is more beneficial to do the exercises face-to-face.

\section{Discussion and Conclusion}

The level of physical activity is reduced in older adults (Milanović et al., 2013). There are physical activity guidelines specifically developed for older people (Piercy and Troiano, 2018). While the elderly did not comply with the physical activity guidelines recommended for them even before the pandemic (Sun, Norman and While, 2013), quarantine resulted in a more decrease in the physical activity levels of the elderly (Ekelund et al., 2019). Although quarantine is the best and recommended option to stop the rapid spread of Covid-19 disease, other aspects of the health of the elderly who remain isolated at home in quarantine should also be considered (Jiménez-Pavón, Carbonell-Baeza and Lavie, 2020).

Exercise plays an essential role in maintaining the health of elderly individuals (Lavie et al., 2019), active aging (Fletcher et al., 2018), and combating diseases such as diabetes, hypertension, cardiovascular diseases, respiratory diseases (Ozemek, Lavie and Rognmo, 2019). Some studies 
have shown that exercise positively affects the immune system (Nieman and Wentz, 2019). In a review by Polero et al., aerobic, strength, flexibility, and balance exercises were recommended during the quarantine caused by Covid-19 (Polero et al., 2021). However, it is not always possible for all elderly people to receive a personally planned exercise program from a healthcare professional (Said and Batchelor, 2020). Since we think that different studies are needed to support physical activity and exercise in the home environment of the elderly, we implemented a program consisting of stretching, strength, flexibility, and balance exercises for the elderly during quarantine.

The elderly in the risk group for Covid-19 should be prevented from adopting a sedentary lifestyle during the quarantine process; thus, exercise opportunities should be offered to the elderly. The necessity of online exercise applications drew attention in this period when activities performed together threaten health. However, there are not enough studies on the effect of online exercise on the elderly and the technological competence of the elderly in accessing online exercise. In the present study, it is seen that one of the most important benefits of online exercise in quarantine allows the elderly to be more active by preventing them from being inactive.

It is also mentioned that technology-based interventions are needed to overcome psychosocial difficulties during Covid-19 quarantine (Ammar et al., 2021). Especially, it is necessary to improve telehealth services for vulnerable groups (Said and Batchelor, 2020). Our study should emphasize that technology-based online exercises are practical on the psychological well-being of the elderly. Although they had some difficulties following the exercises online, most of them could follow the online exercise program and do their exercises. We think that it may be beneficial to continue online exercise programs after the quarantine period is over.

Gamberini et al. (2006) state that various factors are connecting older people to technology (Gamberini et al., 2006). One of these elements is telehealth, which is used to diagnose and treat chronic diseases remotely and electronically. During the pandemic period, remote access to health services has become important. Contrary to the negative perception of the elderly in the use of technology in society (Baran, Kurt and Tekeli, 2017), it is impressive that in this study we conducted with elderly individuals 
at 60+ Tazelenme University, the majority of elderly individuals think that their technological devices are sufficient to benefit from online services. We think that the ability of elderly individuals to adapt to the changing daily life process makes a great contribution to the quarantine caused by the pandemic.

The limitation of our study is that the online exercise program can not be prepared specifically for the individual and that a general exercise program is applied to the participants at a level that will not harm individuals with chronic diseases. There is a need for new studies on the evaluation and treatment of the individual online in the literature.

In addition, in the digitized world, elderly individuals have problems in accessing and using technological devices to use the telehealth system. For this reason, in our study, online exercises were performed on platforms that the elderly can easily access. Despite this, in our study, the elderly experienced problems resulting from technological products such as the problem of connecting to the Internet and the small screen.

\section{References}

Ammar, A., Bouaziz, B., Trabelsi, K., Glenn, J., Zmijewski, P., Müller, P., ... and Hökelmann, A. (2021). Applying digital technology to promote active and healthy confinement lifestyle during pandemics in the elderly. Biol Sport, 38(3), 391-396.

Anderson, E. and Durstine, J. L. (2019). Physical activity, exercise, and chronic diseases: A brief review. Sports Medicine and Health Science, 1(1), 3-10.

Baran, A. G., Kurt, Ş. K. and Tekeli, E. S. (2017). Yaşlıların dijital teknolojileri kullanım düzeyleri üzerine bir araştirma. İletişim Kuram ve Araştırma Dergisi, 45, 1-24.

Buffart, L. M., Kalter, J., Sweegers, M. G., Courneya, K. S., Newton, R. U., Aaronson, N. K., ... and Brug, J. (2017). Effects and moderators of exercise on quality of life and physical function in patients with cancer: an individual patient data meta-analysis of 34 RCTs. Cancer treatment reviews, 52, 91-104.

Cadore EL, de Asteasu MLS. and Izquierdo M. (2019) Multicomponent exercise and the hallmarks of frailty: Considerations on cognitive impairment and acute hospitalization. Experimental gerontology, 122, 10-4.

Chen, P., Mao, L., Nassis, G. P., Harmer, P., Ainsworth, B. E. and Li, F. (2020). Wuhan coronavirus (2019-nCoV): The need to maintain regular physical 
activity while taking precautions. Journal of sport and health science, 9(2), 103.

Ekelund, U., Tarp, J., Steene-Johannessen, J., Hansen, B. H., Jefferis, B., Fagerland, M. W., ... and Lee, I. M. (2019). Dose-response associations between accelerometry measured physical activity and sedentary time and all cause mortality: systematic review and harmonised meta-analysis. BMJ, 366, 110.

Fletcher, G. F., Landolfo, C., Niebauer, J., Ozemek, C., Arena, R. and Lavie, C. J. (2018). Promoting physical activity and exercise: JACC health promotion series. Journal of the American College of Cardiology, 72(14), 1622-1639.

Gamberini, L., Raya, M. A., Barresi, G., Fabregat, M., Ibanez, F. and Prontu, L. (2006). Cognition, technology and games for the elderly: An introduction to ELDERGAMES Project. PsychNology Journal, 4(3), 285-308.

Halabchi, F., Ahmadinejad, Z. and Selk-Ghaffari, M. (2020). COVID-19 epidemic: exercise or not to exercise; That is the question. Asian J Sports Med, 11(1), e102630.

Jiménez-Pavón, D., Carbonell-Baeza, A. and Lavie, C. J. (2020). Physical exercise as therapy to fight against the mental and physical consequences of COVID-19 quarantine: Special focus in older people. Progress in cardiovascular diseases, 63(3), 386.

Laslett, P. (1991). A fresh map of life: The emergence of the third age. Cambridge: Harvard University Press.

Lavie, C. J., Ozemek, C., Carbone, S., Katzmarzyk, P. T. and Blair, S. N. (2019). Sedentary behavior, exercise, and cardiovascular health. Circulation research, 124(5), 799-815.

Liu, Y., Lee, D. C., Li, Y., Zhu, W., Zhang, R., Sui, X., ... and Blair, S. N. (2019). Associations of resistance exercise with cardiovascular disease morbidity and mortality. Medicine and science in sports and exercise, 51(3), 499.

Milanović, Z., Pantelić, S., Trajković, N., Sporiš, G., Kostić, R. and James, N. (2013). Age-related decrease in physical activity and functional fitness among elderly men and women. Clinical interventions in aging, 8, 549.

Nieman, D. C. and Wentz, L. M. (2019). The compelling link between physical activity and the body's defense system. Journal of sport and health science, 8(3), 201-217.

Owen, N., Sparling, P. B., Healy, G. N., Dunstan, D. W., and Matthews, C. E. (2010). Sedentary behavior: emerging evidence for a new health risk. In Mayo Clinic Proceedings, 85(12), 1138-1141. 
Ozemek, C., Lavie, C. J. and Rognmo, Ø. (2019). Global physical activity levelsNeed for intervention. Progress in cardiovascular diseases, 62(2), 102-107.

Piercy, K. L. and Troiano, R. P. (2018). Physical activity guidelines for Americans from the US department of health and human services: Cardiovascular benefits and recommendations. Circulation: Cardiovascular Quality and Outcomes, 11(11), e005263.

Polero, P., Rebollo-Seco, C., Adsuar, J. C., Pérez-Gómez, J., Rojo-Ramos, J., Manzano-Redondo, F., ... and Carlos-Vivas, J. (2021). Physical activity recommendations during COVID-19: Narrative review. International Journal of Environmental Research and Public Health, 18(1), 65.

Sagar, V. A., Davies, E. J., Briscoe, S., Coats, A. J., Dalal, H. M., Lough, F., ... and Taylor, R. S. (2015). Exercise-based rehabilitation for heart failure: systematic review and meta-analysis. Open heart, 2(1), 1-12.

Said, C. M., Batchelor, F. and Duque, G. (2020). Physical activity and exercise for older people during and after the coronavirus disease 2019 pandemic: A path to recovery. Journal of the American Medical Directors Association, 21(7), 977.

Sherrington, C., Whitney, J.C., Lord, Stephen R., Herbert, Robert D., Cumming, Robert G et al. (2008). Effective exercise for the prevention of falls: A systematic review and meta-analysis. Journal of the American Geriatrics Society, 56(12), 2234-43.

Sun, F., Norman, I. J. and While, A. E. (2013). Physical activity in older people: a systematic review. BMC public health, 13(1), 1-17.

Uzunsakal, E. and Yıldız, D. (2018). Alan araştırmalarında güvenilirlik testlerinin karşılaştırılması ve tarımsal veriler üzerine bir uygulama. Uygulamah Sosyal Bilimler Dergisi, 2(1), 14-28.

Yazıcıŏ̆lu, Y. and Erdoğan, S. (2007). SPSS uygulamalı bilimsel araştırma yöntemleri. Ankara: Detay Yayıncilı.

\section{Citation Information}

Güneş Gencer, G. Y., Özgür, Ö., Dinç, S. and Nakajima, H. (2021). Online exercise program for elderly during Coronavirus (Covid-19) Pandemic. OPUS-International Journal of Society Studies, 18(44), 75817593. DOI: $10.26466 / o p u s .934919$. 